\title{
ANALYZING RELATIONSHIP BETWEEN LAND USE/LAND COVER AND LAND SURFACE TEMPERATURES OVER BHILWARA DISTRICT USING GEOSPATIAL TECHNIQUES
}

\author{
Urmi SHARMA $^{1}$, Seema JALAN ${ }^{2}$, Yogesh KANT $^{3}$ and Rajesh Kumar YADAV ${ }^{4}$ \\ ${ }^{1}$ Assistant Professor (\& Research scholar), MLS University, Udaipur \\ ${ }^{2}$ Professor, MLS University, Udaipur \\ ${ }^{3}$ Scientist S'E', MASD, IIRS (ISRO), Dehradun \\ ${ }^{4}$ SRF, MLS University, Udaipur
}

DOI: 10.46609/IJSSER.2021.v06i05.010 URL: https://doi.org/10.46609/IJSSER.2021.v06i05.010

\begin{abstract}
Land use land cover (LULC) changes on the surface of the earth are classic manifestation of the relationship between man and his environment. Various studies have analyzed LULC changes and land surface temperatures (LST) to study the environmental livability and sustainability, especially of urban areas. The combination proves reasonable to understand the variations in surface heat fluxes due to changing landscape dynamics. The present study investigates LST variations over Bhilwara district in correspondence to the land cover distribution. Multi-spectral satellite data of Landsat 8 OLI and TIRS (October, 2017) have been used to derive LULC and LST patterns in the region. Supervised classification using maximum likelihood classifier has been employed to map seven LULC classes: water body, agriculture cropped, agriculture fallow, vegetation/grass, built-up, scrub and barren. Thermal bands of the satellite data have been used to estimate LST by applying NDVI threshold methods. Results show a high correlation between spatial patterns of LULC and LST. 'Agriculture fallow' and 'barren' classes correspond to highest surface temperatures followed by 'scrub' and 'built-up' while the lowest temperatures are recorded over 'water' and 'vegetation/grass'. The study underlines immense potential of geospatial technique to address dynamic environmental issues at regional level.
\end{abstract}

Keywords: Land Use/ Land Cover, LST, Remote Sensing, Emissivity, NDVI

\section{Introduction}

Geographers have always been interested in analyzing how man uses and organizes his space [1]. His actions lead to alteration of his natural milieu. This transformation occurs in a cyclic way initially by affecting the environment and then man himself. At many occasions, this impact is so 
International Journal of Social Science and Economic Research

ISSN: 2455-8834

Volume:06, Issue:05 "May 2021"

strong and dangerous that it becomes almost irreversible. Rapid climatic changes due to actions of man in the world is one such phenomena [2].

Various studies have analyzed the impact of man's activity over transforming the natural land cover. They used the cutting-edge technology of geospatial techniques to identify changes taking place over a greater period of time and over extensive areas [3-4]. There have also been researches organized to relate this land cover transformation to the satellite derived land surface temperature (LST) to examine changes in the local climate of the region [5-6].

The present study is an attempt to establish the relationship between land use/land cover scenario with corresponding land surface temperatures for Bhilwara district using satellite-based parameters. The study also investigates the problems associated with high LST regions and suggestions to be taken into consideration by the planning authorities.

\section{Study Area}

Bhilwara district is one of the emerging regions holding significant position in the textile industry and mineral deposits not only in Rajasthan but also in India. In Fig1 it is situated between $29^{\circ} 4 \& 25^{\circ} 58^{\prime}$ north latitudes and $74^{\circ} 1^{\prime} \& 75^{\circ} 28^{\prime}$ east longitudes in the south-eastern part of the Rajasthan covering a total area of $10,455 \mathrm{sq} . \mathrm{km}$ (3.05\% of the state). It is dominantly a plain region drained by river Banas and its tributaries. The region is intersected by part of Aravalli range in the north-east.

With a population of 24,08,523 and population density at 230 persons /sq. $\mathrm{km}$ the district holds $10^{\text {th }}$ rank in terms of population in the state. The decadal population growth during $2001-2011$ has been $19.18 \%$. The district occupies $12^{\text {th }}$ rank in terms of urban population $(21.28 \%)$ in the state $(24.87 \%)$. Bhilwara city is the district headquarter which is the $6^{\text {th }}$ largest city by urban population in Rajasthan. The urban population growth rates for 2001-2011 of district's major cities have been Bhilwara (28.33\%), Hameergarh (19.81\%), Asind (17.62\%), Beejoliya (14.13\%), Gulabpura (11.71\%) and Shahpura (9.1\%) [7]. 


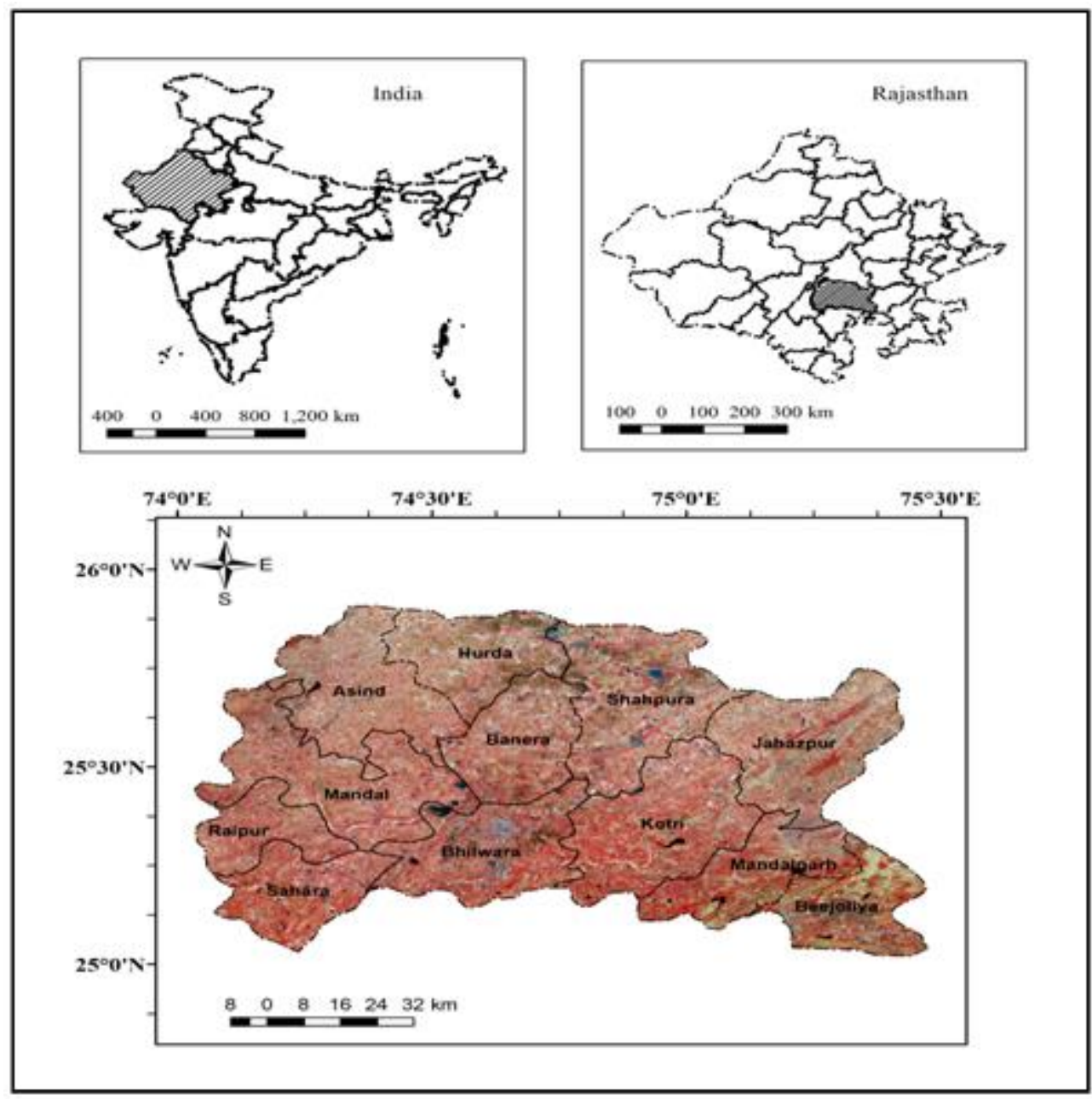

Fig1: Location map of Bhilwaradistrict

The district is one of the leading industrial regions in the field of textiles and is popularly known as the 'Manchester of Rajasthan'. In the district textile industries are showing 8-10\% annual growth. Most of the industries export their products like textile, synthetic yarn, cotton yarn, woolen products and fabric cloths to various parts of the country [8]. The major textile industries are located in: Bhilwara, Gulabpura and Hameergargh areas.

The district is also well known for its huge variety of minerals mainly zinc, soap stone, china clay, feldspar, quartz, mica, asbestos and garnet. The major mining areas are Hurda, Mandalgarh, Beejoliyan and Jahazpur (sandstone mining). The availability of minerals has also attracted various manufacturing industries based on them to the district.

The growth potential of the region is further stimulated by the fact that Bhilwara-Rajsamand industrial area has become the part of Delhi-Mumbai Industrial Corridor. The district is also 
well-connected to major urban centres of Ajmer, Jaipur and Udaipur of Rajasthan which ensures its advantages to develop as a fast-growing industrial region.

\section{Materials and Methods}

\subsection{Satellite data and pre-processing}

A set of four cloud free level 1 (T1) Landsat 8 TIRS and OLI tiles acquired in October, 2017 covering Bhilwara district has been procured from USGS Earth Explorer website [9]. The details of the satellite data have been shown in Table 1.

Table 1: Band specifications of Landsat 8 satellite data used

\begin{tabular}{|l|c|c|}
\hline Bands & Spatial resolution & Spectral resolution $(\boldsymbol{\mu m})$ \\
\hline Band 3 (Green) & $30 \mathrm{~m}$ & $0.53-0.59$ \\
\hline Band 4 (Red) & $30 \mathrm{~m}$ & $0.64-0.67$ \\
\hline Band 5 (NIR) & $30 \mathrm{~m}$ & $0.85-0.88$ \\
\hline Band 10 (Thermal Infrared) (TIRS 1) & $100 \mathrm{~m}($ resampled at 30 m) & $10.6-11.19$ \\
\hline
\end{tabular}

Source: NASA USGS Earth Explorer

The data has been corrected for atmospheric effects using FLAASH (Fast Line-of-sight Atmospheric Analysis of Spectral Hypercubes) model in ENVI 5.3 using multispectral bands. Fig2 shows the methodological flowchart of the present study. 
International Journal of Social Science and Economic Research

ISSN: $2455-8834$

Volume:06, Issue:05 "May 2021"

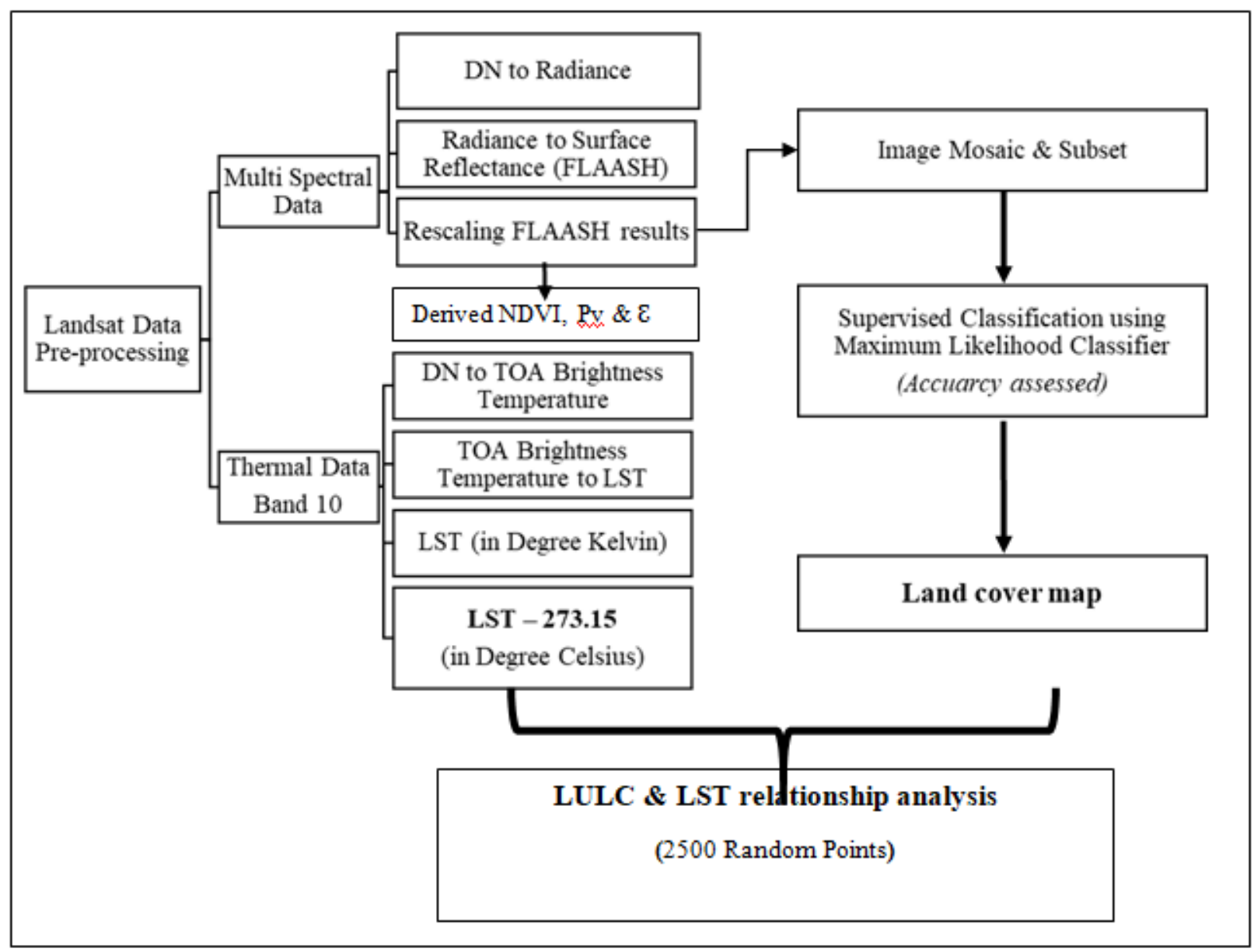

Fig2: Methodological flowchart

The absolute atmospheric correction is based on the following equations and metadata information of the satellite data taken by the software in the background.

\section{- DN to Radiance conversion}

$$
L_{\lambda}=M_{L} \times Q_{c a l}+A_{L}
$$

where:

$L_{\lambda}$ is TOA spectral radiance (Watts/ $\left.\left(\mathrm{m}^{2} \times \operatorname{srad} \times \mu \mathrm{m}\right)\right), M_{L}$ is band-specific multiplicative rescaling factor, $A_{L}$ is band-specific additive rescaling factor and $Q_{c a l}$ is quantized and calibrated standard product pixel values (DN).

- Radiance to Surface Reflectance 
International Journal of Social Science and Economic Research

ISSN: 2455-8834

Volume:06, Issue:05 "May 2021"

FLAASH converts bands having wavelengths in the visible through near-infrared and shortwave infrared regions, up to $3 \mu \mathrm{m}$ from radiance image to reflectance image [10]. The reflectance results were further rescaled using rescaling equation [11] in ENVI using band math tool:

(b1 le 0$)^{*} 0+($ b1 ge 10000)*1 + (b1 gt 0 and b1 lt 10000)*float (b1) / 10000

- where $b 1$ is the surface reflectance output obtained from FLAASH result

- le, ge, gt, lt are band math relational operators in ENVI for 'greater than equal to', 'less than equal to', 'greater than' and 'less than' respectively

- Radiance to TOA brightness temperature

$$
T O A=\frac{K_{2}}{\ln \left(\frac{K_{1}}{L_{\lambda}}+1\right)}
$$

where:

TOA is top-of-atmosphere brightness temperature $(\mathrm{K})$ and $\mathrm{K}_{1} \& \mathrm{~K}_{2}$ are band-specific thermal conversion constants $777.89 \& 1321.08$ respectively.

The individual tiles were then mosaicked using bands green, red and NIR to build false color composite and clipped to the extent of the study area using Bhilwara district boundary generated in ArcGIS 10.2.

\subsection{Land Use/Land Cover (LULC) Mapping}

Supervised classification technique using maximum likelihood classifier has been performed in Erdas Imagine 2014 software to map land use/land cover of Bhilwara district. Seven land cover classes have been selected on the basis of National Remote Sensing Centre (NRSC), Hyderabad level 1 classification scheme [12]. The classes are: water body, scrub, barren, built-up, agriculture cropped, agriculture fallow and vegetation/ grass. Water body includes rivers, lakes and tanks filled with water. Scrub includes mostly dry shrubs over a piece of land. Barren is referred to either rocky topography or often devoid of vegetation cover. A built-up area is defined as an area of human habitation developed due to non-agricultural use and that has a cover of buildings, transport and communication utilities. It also includes mining areas in the present study. The vegetation/grass includes areas with trees and grass i.e. green land cover which is not agriculture. The agriculture cropped refers to the land cover which has standing crop. The agriculture fallow includes temporarily uncropped cultivable land. This understanding of agriculture land cover including both cropped and fallow has been considered in context of date of satellite overpass during data collection. The deviations in class definitions from the 
NRSC scheme have been incorporated in order to establish a more reliable relationship between land cover type and its surface temperature.

Accuracy assessment was performed for 250 stratified random sampling points with a minimum of 10 points for each class. Class-wise results of accuracy assessment have been summarized in Table 2.

Table 2: Results of accuracy assessment of the LULC map

\begin{tabular}{|c|c|c|c|}
\hline$L U L C$ & 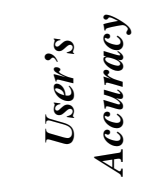 & 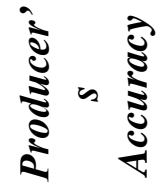 & 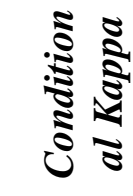 \\
\hline Scrub & 85 & 82.93 & 0.8206 \\
\hline Barren & 85.94 & 90.16 & 0.814 \\
\hline $\begin{array}{c}\text { Vegetation/ } \\
\text { Grass }\end{array}$ & 94.12 & 84.21 & 0.9363 \\
\hline Built-up & 93.33 & 87.5 & 0.9288 \\
\hline $\begin{array}{c}\text { Agriculture } \\
\text { Fallow }\end{array}$ & 95.45 & 80 & 0.9493 \\
\hline Water body & 100 & 100 & 1 \\
\hline $\begin{array}{l}\text { Agriculture } \\
\text { Cropped }\end{array}$ & 90.24 & 96.10 & 0.859 \\
\hline \multicolumn{4}{|c|}{ Overall accuracy $=89.60 \%$} \\
\hline
\end{tabular}

\subsection{Land Surface Temperature Mapping}

Band 10 of Landsat 8 satellite has been used to estimate land surface temperatures (LSTs) using normalized difference vegetation index (NDVI) threshold methods [13]. USGS recommends user to avoid using thermal band 11 due to its larger calibration uncertainty to retrieve surface temperature [14].

The most important component of retrieving LST is land surface emissivity (LSE). It is a factor that describes how efficiently an object radiates energy as compared to the blackbody [15]. Various methods have been used to calculate LSE [16-19]. NDVI threshold method is used [18, 20-22] which assumes that the surface component is made of a mixture of bare soil and vegetation [23]. The process of retrieving LST has been elaborated in following sections:

\subsubsection{Calculating Normalized Difference Vegetation Index (NDVI)}


NDVI is one of the popular vegetation indices derived using satellite data to estimate the healthiness of the vegetation. NDVI is calculated as follows [24]

$$
N D V=\frac{N I R-R e d}{N I R+R e d}
$$

where NIR is the near infrared band (band 5) and Red is red band (band 4)

\subsubsection{Calculating Proportionate Vegetation Index $(P v)$}

$P v$ is the vegetation proportion viewed by the sensor and is obtained as following [25]:

i) If NDVI $<0 ; P v=0$ as for non-vegetative surfaces $P v$ has to be zero [23]

ii) If NDVI > 0.73; assuming that the pixel is fully vegetated $P v=1[20]$

iii) For pixels with NDVI value between 0 and $0.73 P v$ is derived using the following equation:

$$
P v=\left[\frac{N D V I-N D V I \min }{N D V I \max -N D V I \min }\right]^{2}
$$

where NDVI $\max$ is for vegetation while NDVI $\min$ is for bare ground [26]. Here we have assigned NDVI $\max =0.73$ and NDVI $\min =0.05$ after [20].

\subsubsection{Calculating land surface emissivity $(\varepsilon)$ :}

The pixel-wise land surface emissivity is calculated as:

$$
\varepsilon=\varepsilon v P v+\varepsilon s(1-P v)+d \varepsilon
$$

where $\varepsilon v=0.9863, \varepsilon s=0.9668$ are the emissivities of the vegetation and soil respectively [20] and $d \mathcal{E}=0.004$ (approximation), the mean weighted value that takes into account the mean of emissivity value of different surface types [27].

\subsubsection{Calculating land surface temperature (LST):}

$$
L S T=\frac{\mathrm{TOA}}{\{1+[(\lambda * \mathrm{TOA} / \rho) \ln \varepsilon]\}}-273.15
$$

where TOA is at-sensor brightness temperature (in kelvin), $\lambda$ is the wavelength of emitted radiance (for which the peak response and the average of the limiting wavelengths $=10.895$ $\mu m$ ) (Band 10), $\varepsilon$ is the emissivity calculated in (3) and $\rho=\mathrm{h} \times \mathrm{c} / \sigma=1.438 \times 10^{-2} \mathrm{mK}$, which is further converted to $\mu m$ units before putting into the equation (4), here $h$ is Planck's constant $\left(6.626 \times 10^{-34} \mathrm{Js}\right), \sigma$ is the Boltzmann constant $\left(1.38 \times 10^{-23} \mathrm{~J} / \mathrm{K}\right)$ and $c$ is the velocity of light $\left(2.998 \times 10^{8} \mathrm{~m} / \mathrm{s}\right)$ [13]. 


\section{Results and Discussions}

\subsection{Land use/ land cover analysis}

The spatial distribution of the various LULC classes has been shown in Fig3 (a). The overall accuracy of the classified results is $89.60 \%$ with kappa coefficient of 0.8684 . The class-wise area has also been calculated (Table 3 and Fig3 (a)). The agriculture cropped occupies the highest area within $(37.5 \%)$ the district. Though it is evenly distributed across the whole district along riversides and around settlements, higher concentration occurs in the southern half of the district. Barren and scrub together constitute around $44.6 \%$ of the area. The barren is uniformly distributed all over the region and is found mixed with scrub patches. An extensive area dominating barren exists in the south-eastern portion under Mandalgarh and Beejoliya tehsils as part of Hadoti plateau. The vegetation/grass is found as few scattered patches covering 5\% of the total area. Although built-up comprises only $4 \%$ of the total area but it occurs in large patches major area being Bhilwara city, mining areas of Hurda tehsil (Rampura-Agucha mines of Lead and Zinc) in the north and Beejoliya tehsil (sandstone mines) in the south-east. The agriculture fallow is found widely distributed in the northern and south-eastern part of the district covering a total area of $7.4 \%$. The water body is found dispersed all over the region as deep and shallow ponds, tanks and rivers.

Table 3: Area under different LULC classes

\begin{tabular}{|c|c|c|}
\hline Land Use/Land Cover & Area in sq. $\mathrm{km}$ & Area in Percentage \\
\hline Agriculture Cropped & 3922.4 & 37.5 \\
\hline Barren & 3160.5 & 30.2 \\
\hline Scrub & 1508.5 & 14.4 \\
\hline Agriculture Fallow & 773.8 & 7.4 \\
\hline Vegetation /Grass & 518.5 & 5.0 \\
\hline Built up & 419.2 & 4.0 \\
\hline Water body & 152.2 & 1.5 \\
\hline Total & $\mathbf{1 0 , 4 5 5}$ & $\mathbf{1 0 0 . 0}$ \\
\hline
\end{tabular}


International Journal of Social Science and Economic Research

ISSN: 2455-8834

Volume:06, Issue:05 "May 2021"

\subsection{Land Surface Temperatures analysis}

Fig3 (b) shows spatial distribution of LST across Bhilwara district. The LST for the district ranged between $23.53^{\circ} \mathrm{C}$ to $44.56^{\circ} \mathrm{C}$. The result exhibits a clear north-south divide in the LSTs with northern half of the region consisting parts of Hurda, Shahpura, Jahazpur, Banera and northern Kotri tehsils recording highest LSTs of above $39^{\circ} \mathrm{C}$. Naturally, these areas have large proportion of barren, scrub and agriculture fallow. The human induced mining areas in this region also conform with the high LST areas. The southern half of the district comprising Mandal, Raipur, Sahara, Bhilwara, parts of Kotri tehsils is mainly dominated by moderate LSTs ranging between $34^{\circ} \mathrm{C}$ and $37^{\circ} \mathrm{C}$ The built-up areas of Bhilwara city, Hameergarh town, mining areas of Beejoliya and Mandalgarh tehsils record moderate to high range of LSTs. The lowest LSTs are estimated over water bodies and vegetated areas. This region constitutes substantial amount of agriculture cropped lands as compared to rest of the parts.

To examine the relationship between LST and corresponding land cover, a total of 2500 random sample points were generated in Quantum GIS. The minimum, maximum and mean surface temperature values of those locations with corresponding land cover type were recorded from both LST and LULC results (Table 4 and Fig4). The highest mean LST corresponds to agriculture fallow with value of $38.25^{\circ} \mathrm{C}$ followed by barren with $37.65^{\circ} \mathrm{C}$ and scrub with $37.27^{\circ} \mathrm{C}$. The built-up records mean LST of $36.02^{\circ} \mathrm{C}$ ranging between $33.83^{\circ} \mathrm{C}$ to $39.9^{\circ} \mathrm{C}$. Vegetation/grass and agriculture cropped areas are observed with low mean LSTs of $34.75^{\circ} \mathrm{C} \&$ $34.95^{\circ} \mathrm{C}$ respectively. The water areas exhibit lowest mean LST of $28.44^{\circ} \mathrm{C}$ and also minimum and maximum LSTs among all classes. It has been observed that the agriculture fallow distributed in the southern portion of the district has high moisture content as compared to the northern one. Therefore, relatively low LSTs are recorded over them. Vegetation areas with large continuous extent have recorded lower LST as compared to the scattered patches mainly those inter-mixed with built-up areas. The temperature of the shallow water bodies is higher as compared to the deep and large water bodies. 


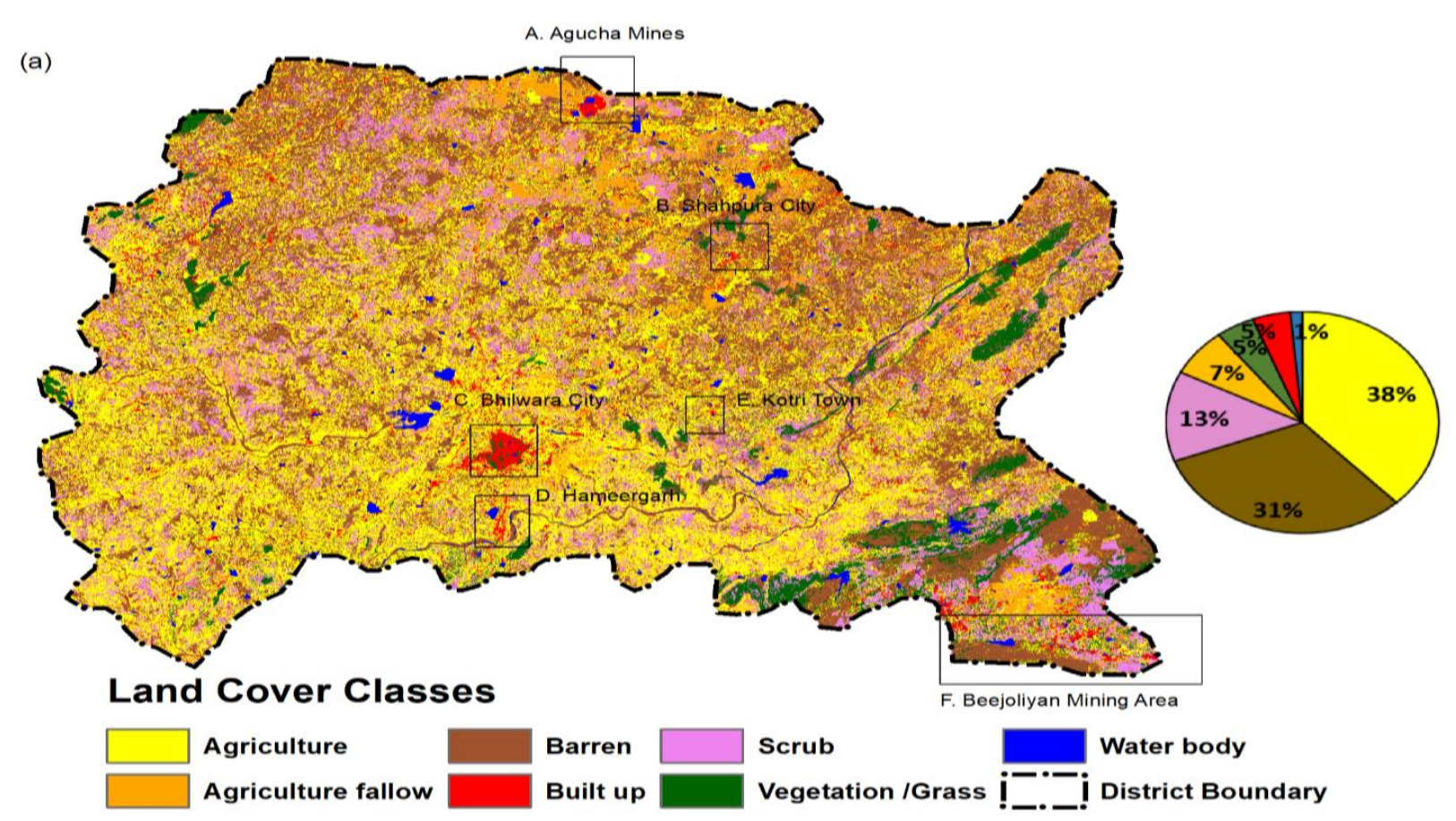

(b)

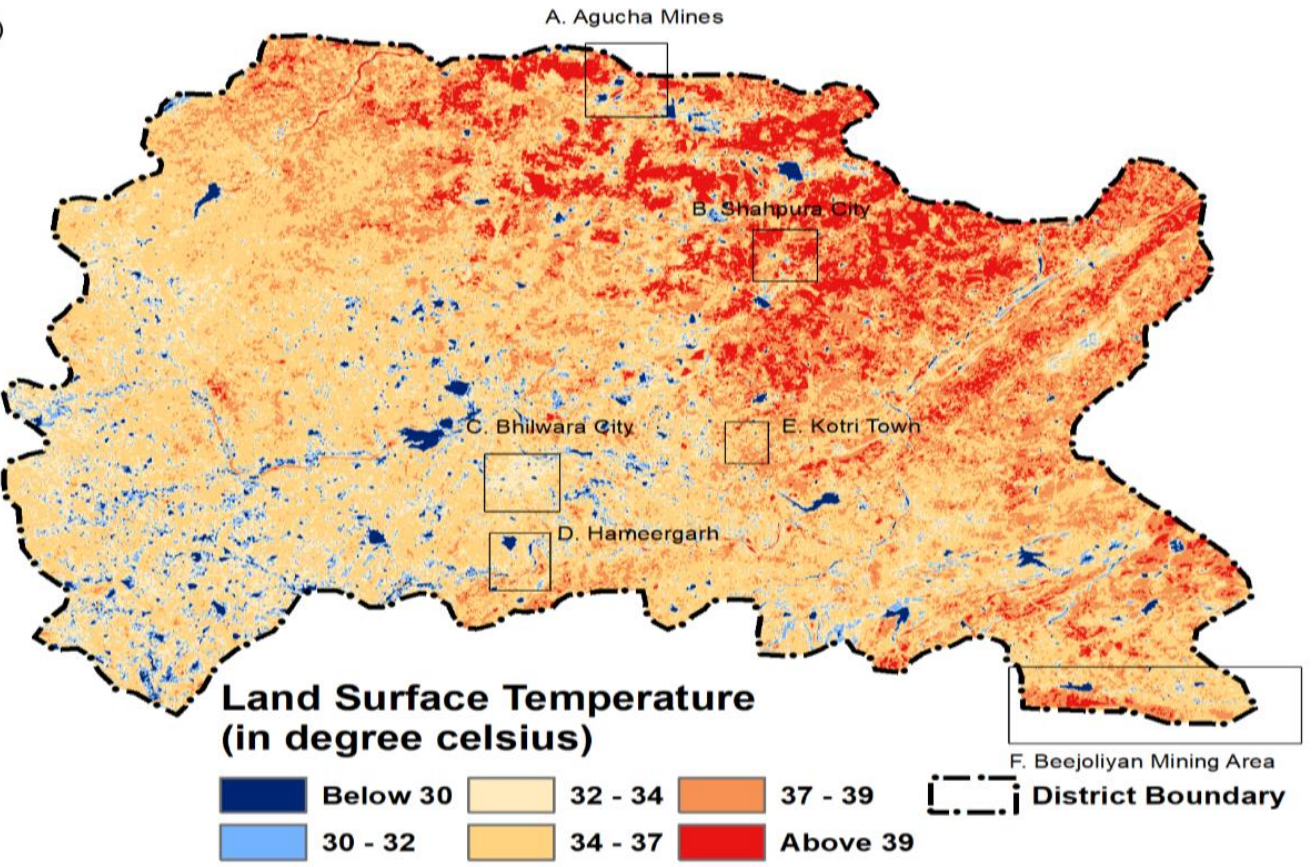

Fig3: (a) Land Use/ Land Cover map of Bhilwara district for October, 2017 and (b) Land Surface Temperature map of Bhilwara district for October,2017. (a-f) have been explained in the text section $4.1 \& 4.2$ 
International Journal of Social Science and Economic Research

ISSN: 2455-8834

Volume:06, Issue:05 "May 2021"

Table 4: Class-wise statistics of LST value (in degree Celsius) along with total number of random points corresponding to various LULC classes

\begin{tabular}{|l|cccccc|}
\hline Land Cover & $\begin{array}{c}\text { Mean } \\
\text { LST }\left({ }^{\circ} \mathbf{C}\right)\end{array}$ & $\begin{array}{c}\text { Min. } \\
\text { LST }\left({ }^{\circ} \mathbf{C}\right)\end{array}$ & $\begin{array}{c}\text { Max. LST } \\
\left({ }^{\circ} \mathbf{C}\right)\end{array}$ & SD & CV in \% & $\begin{array}{c}\text { No. of } \\
\text { Random } \\
\text { points }\end{array}$ \\
\hline Agriculture fallow & $\mathbf{3 8 . 2 5}$ & 31.19 & 41.76 & 2.20 & 5.76 & 187 \\
Barren & $\mathbf{3 7 . 6 5}$ & 34.43 & 41.45 & 1.37 & 3.63 & 775 \\
Scrub & $\mathbf{3 7 . 2 7}$ & 32.34 & 41.34 & 1.75 & 4.69 & 355 \\
Built-up & $\mathbf{3 6 . 0 2}$ & 33.83 & 39.90 & 1.58 & 4.39 & 93 \\
Vegetation/grass & $\mathbf{3 4 . 7 5}$ & 28.67 & 37.94 & 1.56 & 4.48 & 119 \\
Water body & $\mathbf{2 8 . 4 4}$ & 27.13 & 29.98 & 1.96 & 5.65 & 30 \\
Agriculture & $\mathbf{3 4 . 9 5}$ & 27.53 & 37.395 & 0.95 & 3.36 & 941 \\
cropped & & & & & & \\
\hline
\end{tabular}

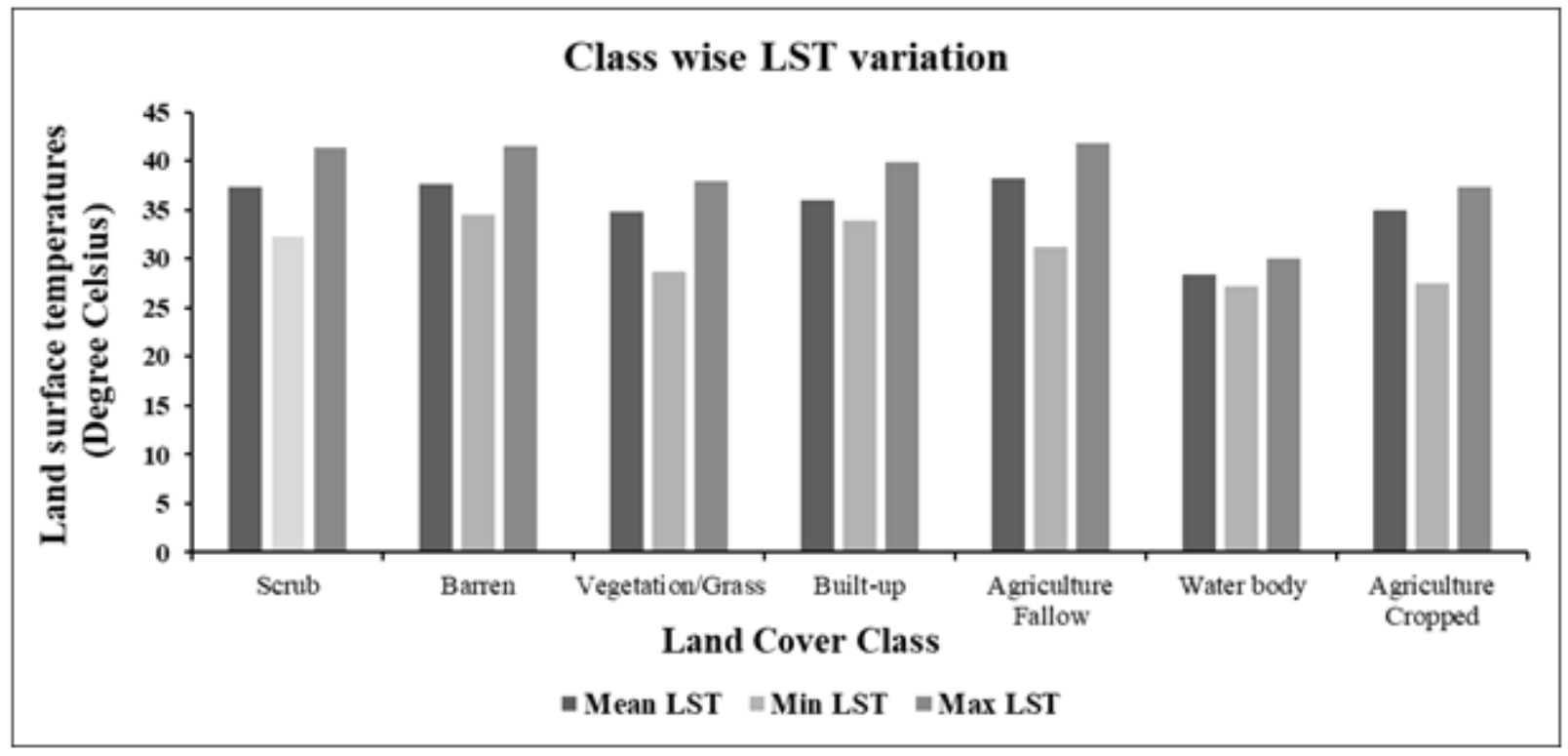

Fig4: LULC class wise LST statistics

The highest standard deviation of 2.2 has been observed over agriculture fallow while the lowest with 0.95 has been for agriculture cropped. 


\section{International Journal of Social Science and Economic Research}

ISSN: $2455-8834$

Volume:06, Issue:05 "May 2021"

\section{Conclusions and Suggestions}

The prime concern of the study has been to explore the surface temperature relationship with present land cover distribution in Bhilwara district. The study reveals a strong relationship between LST and LULC where higher surface temperatures are found over land covers lacking green vegetation or moisture. The built-up areas of Bhilwara city, Hameergarh, Kotri, Shahpura towns and mining areas of Agucha (Hurda), Mandalgarh and Beejoliyan tehsils conforms to comparatively high LST areas.

It has been also observed that this conformity of LST with LULC is occurring in a zonal pattern. The extent of built-up, barren or scrub has been a decisive factor in measuring the intensity of the LST. The study suggests that expansion of the built-up area will lead to intensification of the surface temperatures in those areas. Therefore, it is important for city planners to evaluate the growth of settlements in the district in this context. Provision of green areas may be introduced in a zonal pattern breaking the extent of built-up at specified intervals in the rapidly growing city of Bhilwara and towns of Hameergarh, Asind, Beejoliya, Gulabpura and Shahpura to reduce the intensity of the high LSTs. The economy of the district depends greatly on the mining activities in Hurda and Mandalgrah-Beejoliya tracts. The growth of this economic activity may raise the concern of increasing LST in those areas as apparent in the present investigation. Reclamation of agriculture fallow is another issue to be addressed in this context. Recharging of dry and shallow water bodies should also be given priority as there are many small and widely distributed shallow water bodies in the district. They may act as stabilizer for high LST zones.

\section{References}

[1] Knowles, R., \& Wareing, J. (1976). Economic and Social Geography. Rupa \& Co.

[2] IPCC. (2014). Fifth Assessment Report.

[3] Carlson, T.N., \& Arthur, S.T. (2000). The impact of land use - land cover changes due to urbanization on surface microclimate and hydrology: a satellite perspective. Global and Planetary Change , 49-65.

[4] El-Kawya, O.R.A., Rod, J.K., \& Ismail,H.A. (2011). Land use and land cover change detection in the western Nile delta of Egypt using remote sensing data. Applied Geography, 483-494.

[5] Weng, Q. (2001). A remote sensing-GIS evaluation of urban expansion and its impact on surface temperature in the Zhujiang Delta, China. Inetrnational Journal of Remote Sensing. 


\section{International Journal of Social Science and Economic Research}

ISSN: $2455-8834$

Volume:06, Issue:05 "May 2021"

[6] Choudhury, D., Das, K., \& Das, A. (2019). Assessment of land use land cover changes and its impact on variations of land surface temperature in Asansol-Durgapur Development Region. The Egyptian Journal of Remote Sensing and Space Sciences, 203-218.

[7] Census. (2011). District Census Handbook Bhilwara. Government of India.

[8] Ministry of MSME. (n.d.). Brief Industrial Profile of Bhilwara District. Ministry of MSME, Government of India.

[9] USGS. (n.d.). Retrieved from https://earthexplorer.usgs.gov/

[10] ENVI. (2009). Atmospheric Correction Module QUAC and FLAASH User's Guide. Harris Geospatial Solutions.

[11] (n.d.). Retrieved from https://www.researchgate.net/: https://www.researchgate.net/post/Is_posible_to_obtain_values_higher_than_10000_if_th e_scaling_factor_is_10000_with_FLAASH_on_envi_51

[12] NRSC. (2007). Natural Resource Census - Land Use Land Cover. NRSC, Land Use and Cover Monitoring Division, Hyderabad.

[13] Avdan, U., \& Jovanovska, G. (2016). Algorithm for Automated Mapping of Land Surface Temperature Using LANDSAT 8 Satellite Data. Journal of Sensors.

[14] USGS, N. (n.d.). Retrieved from https://www.usgs.gov/land-resources/nli/landsat/landsat-8oli-and-tirs-calibration-notices.

[15] Lilesand, Thomas M., Kiefer, Ralph W., \& Chipman, Jonathan W. (2004). Remote Sensing and Image Interpretation. Wiley India.

[16] Snyder, W. C, Wan, Z., Zhang, Y., \& Feng, Y.Z. (1998). Classification-based emissivity for land surface temperature measurement from space. Int. J. Remote Sens.,. International Journal of Remote Sensing, 2753 - 2774.

[17] Peres, L. F., \& DaCamara, C.C. (2004). Land surface temperature and emissivity estimation based on the two-temperature method: Sensitivity analysis using simulated MSG/SEVIRI data. Remote Sensing of Environment, 377-389.

[18] Sobrino, J. A., Muñoz, J., Sòria, G., Romaguera, M. , Guanter, L. , Moreno, J., . . Martínez, P. (2008). Land surface emissivity retrieval from different VNIR and TIR sensors. IEEE Transactions on Geoscience and Remote Sensing, 316-327. 
International Journal of Social Science and Economic Research

ISSN: 2455-8834

Volume:06, Issue:05 "May 2021"

[19] Li, Z. L., Wu, H., Wang, N., Qiu, S., Sobrino, J. A., Z. Wan, . . G. Yan. (2013). Land surface emissivity retrieval from satellite data. International Journal of Remote Sensing, 3084 - 3127.

[20] Valor, E., \& Caselles, V. (1996). Mapping land surface emissivity from NDVI: Application to European, African, and South American areas. Remote Sensing of Environment, 57, 167-184,, $167-184$.

[21] Sobrino, J. A, \& Raissouni, N. (2000). Towards remote sensing methods for land cover dynamic monitoring: Application to Morocco. International Journal of Remote Sensing, 353-366.

[22] Peres, L. F. , \& DaCamara, C.C. (2005). Emissivity maps to retrieve land-surface temperature from MSG/SEVIRI. IEEE Transactions on Geoscience and Remote Sensing, $1834-1844$.

[23] Yamamoto, Y. , \& Ishikawa, H. (2017). Thermal Land Surface Emissivity for Retrieving Land Surface Temperature from Himawari-8. Journal of Meteorological Society of Japan.

[24] Rouse, J. W., Haas, R. H., Schell, J. A. , Deering, D.W., \& Harlan, J.C. (1974). Monitoring the vernal advancement of retrogradation of natural vegetation, NASA / GSFC, Type III, Final Report. Greenbelt, MD.

[25] Carlson, T. N., \& Ripley, D. A. . (1997). On the relation between NDVI, fractional vegetation cover, and leaf area index. Remote Sensing of Environment, 241-252.

[26] Sobrino, J.A. , Munoz, J.C.J. , \& Leonardo, P. (2004). Land surface temperature retrieval from LANDSAT TM 5. Remote Sensing of Environment, 434 - 440.

[27] Mallick, J., Kant, Y., \& Bharat, B. (2008). Estimation of land surface temperature over Delhi using Landsat-7 ETM+. Journal of Indian Geophysical Union, 131-140. 